\title{
Character Association and Path Coefficient Analysis in Mothbean Germplasm
}

\author{
Smrutishree Sahoo*, A.K. Sharma, Sanjay Kumar Sanadya and Anil Kumar \\ Department of Plant breeding and Genetics, Swami Keshwanand Rajasthan Agriculture \\ University, Bikaner- 334006 (Raj.), India
}

*Corresponding author

\begin{abstract}
A B S T R A C T
Keywords

Moth bean, Seed yield, Character association, Path Analysis

\section{Article Info}

Accepted:

06 July 2018

Available Online:

10 August 2018

Correlations and path coefficient analysis were evaluated for twelve characters including seed yield in forty eight germplasm of mothbean along with two check varieties during kharif 2017. The experiment was carried out in Randomized block Design (RBD) with three replications. Seed yield per plant exhibited significant and positive association with harvest index, number of pods per plant, number of primary branches per plant, 100-seed weight and plant height. The characters namely harvest index, biological yield, number of primary branches per plant, days to maturity, pod length, number of pods per plant and days to $50 \%$ flowering had direct positive influence on seed yield per plant. The magnitudes of residual effects were very low which indicated that the twelve characters included in the present study contributed most of the portions of the variability in the seed yield. Therefore these traits can be taken into consideration while exercising selection for seed yield in moth bean.
\end{abstract}

\section{Introduction}

Moth bean belongs to genus Vigna sub family Papilionaceae under the family Leguminaceae (Verdcourt, 1970) with $2 \mathrm{n}=2 \mathrm{x}=22$. The moth bean (Vigna aconitifolia (Jacq.) Marechal) is an important pulse crop of hot arid regions of lndia and adapts to extremes ecological niches particularly extreme drought and hot climatic conditions. The crop is mainly grown in Rajasthan during kharif season. Rajasthan occupies 75 per cent of the total area and 55per cent of the total production of the country by occupying the first position in area (13.87 lakh ha) and production (4.34 lakh tonnes) and productivity $\left(310 \mathrm{~kg} \mathrm{ha}^{-1}\right)$. Uttar Pradesh, Punjab, Haryana and M.P are the other states where it is grown on marginal lands. Moth bean seed is rich source of protein (22-24per cent) and simultaneously cheaper than other pulses therefore, it is consumed by the low income people and tribal community in the rural areas of its growing regions. The national productivity of moth bean is 4 quintals per hectare because it is being grown on poor and marginal oils without applying required inputs. It is a hot weather, drought resistant legume and this fact is supported by its well-developed deep root system. It can tolerate high temperature without any adverse 
effect on flowering and fruit development. It is an important source of hay at par in quality with alfa-alfa (Kennedy and Midson, 1925). It is consumed as human food in the form of dal (mogar), sprouts and green pods as vegetables. It is the principal ingredient of a famous spicy snack Bikaneribhujiya. Moth bean has been a neglected crop from the evolution view point hence; it is the marginal and secondary choice of the farmers. Furthermore, research efforts, wealth of literature are also scarce, scanty and unsystematically available in respect of this legume. More efforts are needed in the direction of adaptation to various environmental condition, new cultural practices, input response as well as high yielding situations.

Correlation co-efficient analysis is a handy technique, which elaborates the degree and extent of relationship among important plant characters and it provides basic criteria for selection and leads to directional model based on yield and its components in the field experiments. Yet, the information it supplies about the nature of association is often incomplete. Path co-efficient analysis, on the other hand, is an efficient statistical technique simply splits the correlation coefficient into the measures of direct and indirect effect of a set of independent variables on the dependent variables that quantify the interrelationship of different components.

For a better insight into the cause and effect relationship between pairs of characters, study of correlation in conjunction with path analysis is essential.

\section{Materials and Methods}

The experimental materials consisting forty eight germplasm along with two check varieties of moth bean procured from AICRP on Moth bean, ARS, SKRAU, Bikaner. The experiment was carried out in RBD with three replications during Kharif2017. By adopting a spacing of $30 \mathrm{~cm}$ between rows and $10 \mathrm{~cm}$ between plants respectively, all the recommended package of practices were followed to raise good and healthy crop stand. Data were collected on twelve yield and yield contributing characters viz., days to 50 per cent flowering, days to maturity, plant height, number of primary branches per plant, pod length, number of pods per plant, number of seeds per pod, 100-seed weight, biological yield per plant, harvest index, seed yield per plant and incidence of yellow mosaic virus. At maturity five plants were selected randomly from each plot and tagged. The data of selected plants were recorded on seed yield per plant(g), number of primary branches per plant, pod length, number of pods per plant, number of seeds per pod, biological yield per plant $(\mathrm{g})$ and incidence of yellow mosaic virus (scale 3-7) being 3- resistant, 5- moderately resistant and 7-susceptible.

The phenotypic, genotypic and environmental correlation coefficients were computed from the phenotypic, genotypic and environmental variance and covariance according to Singh and Chaudhary (1976) and the significance of correlation coefficient was tested. The direct and indirect effects were estimated through path coefficient analysis as suggested by Wright (1921) and elaborated by Dewey and Lu (1959).

\section{Results and Discussion}

In general genotypic correlation coefficients were greater than their corresponding phenotypic correlation co-efficients, indicating the preponderance of genetic variance in expression of characters as well as masking effect of environment in modifying the total expression of the genotypes. Tabasum et al., (2010); Khanpara et al., (2012); Vir and Singh (2015) and Kohakade et al., (2017b) reported the similar result (Table 1 and 2). 
Table.1 Estimation of Phenotypic (P) and Genotypic $(\mathrm{G})$ correlation coefficient for twelve characters in moth bean

\begin{tabular}{|c|c|c|c|c|c|c|c|c|c|c|c|c|c|}
\hline & & $\begin{array}{c}\text { Days to } \\
50 \% \\
\text { flowering }\end{array}$ & $\begin{array}{l}\text { Days to } \\
\text { Maturity }\end{array}$ & $\begin{array}{l}\text { Plant } \\
\text { height } \\
(\mathrm{cm})\end{array}$ & $\begin{array}{l}\text { Number of primary } \\
\text { branches per plant }\end{array}$ & $\begin{array}{l}\text { Pod } \\
\text { length } \\
(\mathrm{cm})\end{array}$ & $\begin{array}{c}\text { Number of } \\
\text { pods per } \\
\text { plant }\end{array}$ & $\begin{array}{c}\text { Number of } \\
\text { seeds per } \\
\text { pod }\end{array}$ & $\begin{array}{c}\text { 100-Seed } \\
\text { Weight } \\
(\mathrm{g})\end{array}$ & $\begin{array}{l}\text { Biological } \\
\text { yieldper } \\
\text { plant }(\mathrm{g})\end{array}$ & $\begin{array}{c}\text { Harvest } \\
\text { Index } \\
(\%)\end{array}$ & $\begin{array}{l}\text { Incidence } \\
\text { of YMV }\end{array}$ & $\begin{array}{l}\text { Seed yield } \\
\text { per plant } \\
(\mathrm{g})\end{array}$ \\
\hline \multirow{2}{*}{$\begin{array}{l}\text { Days to } \\
50 \% \text { flowering }\end{array}$} & $\mathrm{P}$ & 1 & $0.256 * *$ & -0.156 & 0.092 & $0.170^{*}$ & $-0.204 *$ & $0.171^{*}$ & 0.042 & $0.184^{*}$ & -0.136 & $0.334 * *$ & -0.079 \\
\hline & G & 1 & $0.320 * *$ & -0.126 & $0.167 *$ & $\begin{array}{c}0.282 * \\
*\end{array}$ & $-0.274 * *$ & $0.207 * *$ & 0.064 & $0.289 * *$ & $-0.177 *$ & $0.474 * *$ & -0.089 \\
\hline \multirow[t]{2}{*}{ Days to maturity } & $\mathrm{P}$ & & 1 & $-0.266^{* *}$ & -0.120 & -0.082 & -0.144 & $-0.170 *$ & $-0.273 * *$ & $0.192 *$ & $-0.386 * *$ & $0.264 * *$ & $-0.327 * *$ \\
\hline & G & & 1 & $-0.312 * *$ & -0.139 & -0.157 & $-0.178 *$ & $-0.186^{*}$ & $-0.304 * *$ & $0.214 * *$ & $-0.420 * *$ & $0.357 * *$ & $-0.352 * *$ \\
\hline \multirow[t]{2}{*}{ Plant height $(\mathrm{cm})$} & $\mathrm{P}$ & & & 1 & 0.063 & 0.120 & 0.150 & -0.034 & $0.213 * *$ & $-0.165^{*}$ & $0.294 * *$ & $-0.171^{*}$ & $0.253^{* *}$ \\
\hline & G & & & 1 & 0.072 & $0.172 *$ & $0.204 * *$ & -0.038 & $0.230 * *$ & $-0.192 *$ & $0.318^{* *}$ & $-0.178 *$ & $0.265^{* *}$ \\
\hline \multirow{2}{*}{$\begin{array}{c}\text { No. of primary } \\
\text { branches per } \\
\text { plant }\end{array}$} & $\mathrm{P}$ & & & & 1 & -0.055 & 0.089 & -0.154 & 0.095 & 0.156 & $0.243 * *$ & -0.085 & $0.362 * *$ \\
\hline & G & & & & 1 & -0.033 & $0.184 *$ & -0.159 & 0.107 & $0.210 * *$ & $0.329 * *$ & -0.147 & $0.443 * *$ \\
\hline \multirow[t]{2}{*}{ Pod length $(\mathrm{cm})$} & $\mathrm{P}$ & & & & & 1 & -0.133 & 0.104 & 0.142 & 0.086 & 0.018 & 0.010 & 0.063 \\
\hline & G & & & & & 1 & -0.131 & 0.133 & 0.151 & $0.192 *$ & 0.003 & 0.075 & 0.069 \\
\hline \multirow{2}{*}{$\begin{array}{l}\text { Number of } \\
\text { pods per } \\
\text { plant }\end{array}$} & $\mathrm{P}$ & & & & & & 1 & 0.146 & 0.126 & 0.127 & $0.278^{* *}$ & $-0.301 * *$ & $0.392 * *$ \\
\hline & G & & & & & & 1 & $0.223 * *$ & $0.212 * *$ & 0.100 & $0.476^{* *}$ & $-0.514 * *$ & $0.542 * *$ \\
\hline \multirow{2}{*}{$\begin{array}{c}\text { Number of seeds } \\
\text { per pod }\end{array}$} & $\mathrm{P}$ & & & & & & & 1 & -0.027 & -0.035 & 0.076 & -0.054 & 0.066 \\
\hline & G & & & & & & & 1 & -0.029 & -0.059 & 0.092 & -0.079 & 0.067 \\
\hline \multirow{2}{*}{$\begin{array}{l}\text { 100- Seed } \\
\text { Weight (g) }\end{array}$} & $\mathrm{P}$ & & & & & & & & 1 & -0.115 & $0.334 * *$ & $-0.209 * *$ & $0.308 * *$ \\
\hline & G & & & & & & & & 1 & -0.128 & $0.355^{* *}$ & $-0.284 * *$ & $0.317 * *$ \\
\hline \multirow{2}{*}{$\begin{array}{c}\text { Biological yield } \\
\text { per plant (g) }\end{array}$} & $\mathrm{P}$ & & & & & & & & & 1 & $-0.413 * *$ & -0.019 & -0.014 \\
\hline & G & & & & & & & & & 1 & $-0.334 * *$ & -0.024 & -0.020 \\
\hline \multirow{2}{*}{$\begin{array}{l}\text { Harvest } \\
\text { Index } \\
(\%)\end{array}$} & $\mathrm{P}$ & & & & & & & & & & 1 & $-0.332 * *$ & $0.899 * *$ \\
\hline & G & & & & & & & & & & 1 & $-0.470 * *$ & $0.943 * *$ \\
\hline \multirow{2}{*}{$\begin{array}{c}\text { Incidence of } \\
\text { YMV }\end{array}$} & $\mathrm{P}$ & & & & & & & & & & & 1 & $-0.387 * *$ \\
\hline & G & & & & & & & & & & & 1 & $-0.510 * *$ \\
\hline
\end{tabular}

*** Significant at $5 \%$ and $1 \%$ level of significance, respectively 
Table.2 Direct (diagonal) and indirect effects (non-diagonal) of different characters on seed yield per plant in moth bean

\begin{tabular}{|c|c|c|c|c|c|c|c|c|c|c|c|c|c|}
\hline Characters & & $\begin{array}{l}\text { Days to } 50 \% \\
\text { flowering }\end{array}$ & $\begin{array}{l}\text { Days to } \\
\text { Maturity }\end{array}$ & $\begin{array}{c}\text { Plant } \\
\text { height }(\mathrm{cm})\end{array}$ & $\begin{array}{l}\text { Number of } \\
\text { primary } \\
\text { branches per } \\
\text { plant }\end{array}$ & $\begin{array}{l}\text { Pod } \\
\text { length } \\
(\mathrm{cm})\end{array}$ & $\begin{array}{c}\text { Number } \\
\text { of pods } \\
\text { per plant }\end{array}$ & $\begin{array}{l}\text { Number } \\
\text { of seeds } \\
\text { per pod }\end{array}$ & $\begin{array}{l}\text { 100-Seed } \\
\text { Weight } \\
\text { (g) }\end{array}$ & $\begin{array}{l}\text { Biological } \\
\text { yield per } \\
\text { plant }(g)\end{array}$ & $\begin{array}{l}\text { Harvest } \\
\text { Index }(\%)\end{array}$ & $\begin{array}{l}\text { Incidenc } \\
\text { e of } \\
\text { YMV }\end{array}$ & $\begin{array}{l}\text { Correlation with } \\
\text { seed yield per } \\
\text { plant }(\mathrm{g})\end{array}$ \\
\hline \multirow{2}{*}{$\begin{array}{l}\text { Days to } \\
\text { 50\%flowering }\end{array}$} & $\mathrm{P}$ & -0.0076 & 0.0049 & -0.0004 & 0.0043 & 0.0036 & -0.0092 & 0.0006 & -0.0002 & 0.0732 & -0.1421 & -0.0066 & -0.0793 \\
\hline & G & 0.0081 & 0.0081 & 0.0009 & 0.0061 & 0.0060 & -0.0052 & -0.0025 & -0.0014 & 0.0861 & -0.1837 & -0.0117 & -0.0892 \\
\hline \multirow[t]{2}{*}{ Days to maturity } & $\mathrm{P}$ & -0.0020 & 0.0190 & -0.0006 & -0.0057 & -0.0018 & -0.0065 & -0.0006 & 0.0014 & 0.0764 & -0.4023 & -0.0052 & $-0.3278 * *$ \\
\hline & G & 0.0026 & 0.0252 & 0.0022 & -0.0051 & -0.0033 & -0.0034 & 0.0022 & 0.0064 & 0.0637 & -0.4343 & -0.0088 & $-0.3526 * *$ \\
\hline \multirow[t]{2}{*}{ Plant height(cm) } & $\mathrm{P}$ & 0.0012 & -0.0051 & 0.0022 & 0.0030 & 0.0026 & 0.0068 & -0.0001 & -0.0011 & -0.0659 & 0.3063 & 0.0034 & $0.2532 * *$ \\
\hline & G & -0.0010 & -0.0079 & -0.0071 & 0.0026 & 0.0037 & 0.0039 & 0.0005 & -0.0049 & -0.0572 & 0.3289 & 0.0044 & $0.2659 * *$ \\
\hline \multirow{2}{*}{$\begin{array}{l}\text { Number of primary } \\
\text { branches per plant }\end{array}$} & $\mathrm{P}$ & -0.0007 & -0.0023 & 0.0001 & 0.0468 & -0.0012 & 0.0040 & -0.0006 & -0.0005 & 0.0622 & 0.2528 & 0.0017 & $0.3623 * *$ \\
\hline & G & 0.0014 & -0.0035 & -0.0005 & 0.0366 & -0.0007 & 0.0035 & 0.0019 & -0.0023 & 0.0628 & 0.3402 & 0.0036 & $0.4430 * *$ \\
\hline \multirow[t]{2}{*}{ Pod length $(\mathrm{cm})$} & $\mathrm{P}$ & -0.0013 & -0.0016 & 0.0003 & -0.0026 & 0.0212 & -0.0060 & 0.0004 & -0.0007 & 0.0344 & 0.0194 & -0.0002 & 0.0632 \\
\hline & G & 0.0023 & -0.0040 & -0.0012 & -0.0012 & 0.0213 & -0.0025 & -0.0016 & -0.0032 & 0.0572 & 0.0038 & -0.0019 & 0.0690 \\
\hline \multirow[t]{2}{*}{$\begin{array}{l}\text { Number of pods } \\
\text { per plant }\end{array}$} & $\mathrm{P}$ & 0.0016 & -0.0027 & 0.0003 & 0.0042 & -0.0028 & 0.0450 & 0.0005 & -0.0006 & 0.0507 & 0.2902 & 0.0059 & $0.3923 * *$ \\
\hline & $\mathrm{G}$ & -0.0022 & -0.0045 & -0.0015 & 0.0067 & -0.0028 & 0.0191 & -0.0027 & -0.0045 & 0.0300 & 0.4917 & 0.0127 & $0.5421 * *$ \\
\hline \multirow{2}{*}{$\begin{array}{l}\text { Number of seeds } \\
\text { per pod }\end{array}$} & $\mathrm{P}$ & -0.0013 & -0.0032 & -0.0001 & -0.0072 & 0.0022 & 0.0066 & 0.0037 & 0.0001 & -0.0143 & 0.0793 & 0.0011 & 0.0668 \\
\hline & G & 0.0017 & -0.0047 & 0.0003 & -0.0058 & 0.0028 & 0.0043 & -0.0119 & 0.0006 & -0.0178 & 0.0959 & 0.0020 & 0.0673 \\
\hline \multirow{2}{*}{$\begin{array}{c}100 \text { Seed Weight } \\
(\mathrm{g})\end{array}$} & $\mathrm{P}$ & -0.0003 & -0.0052 & 0.0005 & 0.0045 & 0.0030 & 0.0057 & -0.0001 & -0.0051 & -0.0461 & 0.3480 & 0.0041 & $0.3089 * *$ \\
\hline & G & 0.0005 & -0.0077 & -0.0016 & 0.0039 & 0.0032 & 0.0041 & 0.0004 & -0.0212 & -0.0382 & 0.3669 & 0.0070 & $0.3174 * *$ \\
\hline \multirow[t]{2}{*}{$\begin{array}{l}\text { Biological yield per } \\
\text { plant }(\mathrm{g})\end{array}$} & $\mathrm{P}$ & -0.0014 & 0.0036 & -0.0004 & 0.0073 & 0.0018 & 0.0057 & -0.0001 & 0.0006 & 0.3980 & -0.4305 & 0.0004 & -0.0149 \\
\hline & G & 0.0023 & 0.0054 & 0.0014 & 0.0077 & 0.0041 & 0.0019 & 0.0007 & 0.0027 & 0.2977 & -0.3452 & 0.0006 & -0.0206 \\
\hline \multirow[t]{2}{*}{ Harvest Index (\%) } & $\mathrm{P}$ & 0.0010 & -0.0073 & 0.0007 & 0.0114 & 0.0004 & 0.0126 & 0.0003 & -0.0017 & -0.1647 & 1.0403 & 0.0065 & $0.8994 * *$ \\
\hline & G & -0.0014 & -0.0106 & -0.0023 & 0.0121 & 0.0001 & 0.0091 & -0.0011 & -0.0075 & -0.0995 & 1.0329 & 0.0116 & $0.9433 * *$ \\
\hline \multirow[t]{2}{*}{ Incidence of YMV } & $\mathrm{P}$ & -0.0025 & 0.0050 & -0.0004 & -0.0040 & 0.0002 & -0.0136 & -0.0002 & 0.0011 & -0.0076 & -0.3461 & -0.0196 & $-0.3878 * *$ \\
\hline & G & 0.0038 & 0.0090 & 0.0013 & -0.0054 & 0.0016 & -0.0098 & 0.0009 & 0.0060 & -0.0071 & -0.4862 & -0.0246 & $-0.5105 * *$ \\
\hline
\end{tabular}


The results on correlation studies revealed that the seed yield per plant exhibited significant and positive association with harvest index $(0.899 * *, 0.943 * *)$, number of pods per plant $(0.392 * *, 0.542 * *)$, number of primary branches per plant $\left(0.362^{* *}\right.$, $0.443 * *), 100$ seed weight $\left(0.308^{* *}, 0.317 * *\right)$ and plant height $\left(0.253^{* *}, 0.265^{* *}\right)$ at both phenotypic and genotypic level. These findings suggested that selection for these characters is likely to be contributed towards high yield. Similar results were found by Khanpara et al., (2012) for number of pods per plant; Tabasum et al., for (2010) pods per plant and harvest index; Vir and Singh (2015) for plant height, pod length and number of branches per plant and Hemavathy et al., (2015) for plant height, 100 seed weight and number of pods per plant.

Significant and negative association of seed yield per plant was found with days to maturity $(-0.327 * *,-0.352 * *)$ (Khanpara et al., (2012) and Raturi et al., (2015)) and incidence of yellow mosaic virus $\left(-0.387^{* *}\right.$, $0.510^{* *}$ ) (Vir and Singh (2015). Hence, improvement in these characters may adversely affect the other and the net gain may be adversely affected.

Among the inter relationships, significant and positive association were exhibited by harvest index with plant height, number of primary branches per plant, number of pods per plant and 100 seed weight; number of pods per plant with harvest index; plant height with 100 seed weight and harvest index; days to 50 per cent flowering with days to maturity, pod length, number of seeds per pod, biological yield and incidence of YMV. These results exhibited that simultaneous selection is possible for all these characters. Similar result was observed by Khanpara et al., (2012).

The results of path analysis indicated that harvest index(1.0329), biological yield
(0.2977), number of primary branches per plant (0.0366), days to maturity (0.0252), pod length (0.0213), number of pods per plant $(0.0191)$ and days to $50 \%$ flowering (0.0081) had direct positive influence on seed yield per plant. It means a slight increase in any of these traits may directly contribute towards seed yield. Similar findings have been observed by Rao et al., (2006); Hemavathy et al., (2015); Garg et al., (2017) for number of pods per plant; Parmeshwarappa and Salimath (2007) for pods per plant, number of branches per plant; Gadakh et al., (2013) for harvest index, biological yield per plant and number of primary branches per plant; Meena et al., (2015) for pod length, days to maturity and primary branches per plant.

Days to $50 \%$ flowering, days to maturity and biological yield per plant had negative association but positive direct effect with seed yield per plant. This may be due to negative indirect influence through characters like harvest index (-0.1837), number of pods per plant(-0.0052), number of seeds per pod($0.0025)$ and 100 -seed weight $(-0.0014)$ on days to $50 \%$ flowering and harvest index($0.4343)$, incidence of YMV(-0.0088), number of primary branches $(-0.0051)$, pod length ($0.0033)$ and number of pods per plant ($0.0034)$ on days to maturity; harvest index(0.3452 ) on biological yield per plant. Kohakade et al., (2017) reported same result for days to maturity in mothbean.

The characters namely plant height, number of seeds per pod and 100 seed weight had positive association with seed yield but their direct effects were negative. Hence, the indirect positive effects seem to be the cause of correlation. Positive indirect effects for plant height via harvest index(0.3289), pod length $(0.0037)$, number of pods per plant (0.0039), number of primary branches per plant (0.0026) and incidence of YMV (0.0044); number of seeds per pod through 
harvest index harvest index (0.0959), incidence of YMV (0.0020), days to 50\% flowering (0.0017), number of pods per plant (0.0043) and pod length (0.0028); 100 seed weight via harvest index harvest index (0.3699), number of primary branches per plant (0.0039), pod length (0.0032), number of pods per plant $(0.0041)$ and incidence of YMV (0.0070) were recorded in the present study.

The residual effects were very low 0.1013 (genotypic) and 0.1818 (phenotypic) which indicated choice of traits in the study were able to explain the most effects on seed yield on moth bean germplasm.

In conclusion, the information from correlation and path coefficient analysis in moth bean will be helping in finding out the structural yield components that can be appropriately incorporated into an improved plant type. Being grown under marginal conditions, it requires a change in the plant type for wider adaptability. Considering the above results it becomes clear that direct selection can be done based on number of pods per plant, number of primary branches per plant and harvest index, which can help for the improvement of seed yield, in moth bean. Plant height and 100- seed weight were having positive significant correlation but having negative direct effects for seed yield, hence considered in simultaneous selection.

\section{References}

Dewey, D.R. and Lu, K.H. (1959). A correlation and path analysis of components of crested wheat grass seed production. Agron. J., 51: 513518.

Expt. Stn. Bull. 39b, University of California, Berkeley- California, Pp. 33.

Gadakh, S.S., Dethe, A.M. and Kathale, M.N. (2013).Genetic variability, correlations and path analysis studies on yield and its component in mungbean. Bioinfolet., 10 (2A): 441447.

Garg, G.K., Verma, P.K. and Harikesh. (2017). Genetic variability, correlation and path analysis in mungbean [Vigna radiata(L.)Wilczek]. Int. J. Curr. Microbiol. App. Sci., 6(11): 21662173.

Hemavathy, A.T., Shunmugavalli, N. and Anand, G. (2015). Genetic variability, correlation and path co-efficient studies on yield and its components in mungbean [Vigna radiate (L.)Wilezek]. Legume Research, 38 (4): 442-446.

Kennedy, P.S. and Midson, B.A. (1925). Mothbean, Phaseoula saconitifolius. California Agric.

Khanpara, M.D., Vachhani, J.H., Jivani, L.L. Jethava, A.S. and Vaghasia, P.M. (2012). Correlation and path coefficient analysis in green gram [Vigna radiata(L.)Wilczek]. Asian Journal of Bio Science, 7(1): 34-38.

Kohakade, S.N., V.V. Bhavsar and Pawar, V.Y. (2017). Correlation and path analysis for different characteristics in germplasm of moth bean [Vignaaconitifolia(Jacq.) Marechal]. Int. J. Curr. Microbiol. App. Sci., 6(11): 2181-2186.

Meena, H.K., Ramkrishna, K. and Sing, B. (2015). Character associations between seed yield and its components traits in cowpea [Vigna unguiculata (L.)Walp.] Indian J. Agric. Res., 49 (6):567-570.

Parmeshwarappa, S.G. and Salimath, P.M. (2007).Studies on genetic variability, characters association and path analysis in green gram. Crop Res. Hisar, 34 (1/3): 195-197.

Rao, G.R., Rao, K. and MallikarjunaRao, C.H. (2006).Genetic divergence in 
mungbean. Indian J. Pulse Res., 19(1): 61-63.

Raturi, A, Singh, S.K, Sharma, V. and Pathak, R. (2015). Genetic variability, heritability, genetic advance and path analysis in mungbean [Vigna radiata (L.)Wilczek]. Legume Research, 38 (2) 2015: 157-163.

Singh, R.K. and Choudhary, B.D. (1976). Variance and covariance analysis. "Biometrical methods in quantitative genetic analysis". Kalyani publication, New Delhi, Pp. 39-68.

Tabasum, A., Saleem, M. And Aziz, I. (2010).Genetic variability, trait association and path analysis of yield and yield components in mungbean
(Vigna radiata(L.)Wilczek). Pak. J. Bot., 42(6): 3915-3924.

Verdcourt, B. (1970). Studies in the leguminosae and papilionideae for flora of tropical east Africa 1l. Kew Bull., 24: 235-307.

Vir O. and Singh, A.K. (2015). Moth bean [Vignaaconitifolia(Jacq.) Marechal] germplasm: Evaluation for genetic variability and inter characters relationship in hot arid climate of western Rajasthan, India. Legume Research, 38 (6): 748-752.

Wright, S. (1921). Correlation and causation. J. Agric. Res., 20: 257-87.

\section{How to cite this article:}

Smrutishree Sahoo, A.K. Sharma, Sanjay Kumar Sanadya and Anil Kumar. 2018. Character Association and Path Coefficient Analysis in Mothbean Germplasm. Int.J.Curr.Microbiol.App.Sci. 7(08): 833-839. doi: https://doi.org/10.20546/ijcmas.2018.708.093 